\title{
Manganese-Catalyzed Cross-Coupling of Aryl Halides and Grignard Reagents by a Radical Mechanism
}

\author{
Antonacci, Giuseppe; Ahlburg, Andreas; Fristrup, Peter; Norrby, Per-Ola; Madsen, Robert
}

Published in:

European Journal of Organic Chemistry

Link to article, DOI:

10.1002/ejoc.201700981

Publication date:

2017

Document Version

Peer reviewed version

Link back to DTU Orbit

Citation (APA):

Antonacci, G., Ahlburg, A., Fristrup, P., Norrby, P-O., \& Madsen, R. (2017). Manganese-Catalyzed CrossCoupling of Aryl Halides and Grignard Reagents by a Radical Mechanism. European Journal of Organic Chemistry, 2017(32), 4758-4764. https://doi.org/10.1002/ejoc.201700981

\section{General rights}

Copyright and moral rights for the publications made accessible in the public portal are retained by the authors and/or other copyright owners and it is a condition of accessing publications that users recognise and abide by the legal requirements associated with these rights.

- Users may download and print one copy of any publication from the public portal for the purpose of private study or research.

- You may not further distribute the material or use it for any profit-making activity or commercial gain

- You may freely distribute the URL identifying the publication in the public portal 


\title{
Manganese-Catalyzed Cross Coupling of Aryl Halides and Grignard Reagents by a Radical Mechanism
}

\author{
Giuseppe Antonacci, ${ }^{[a]}$ Andreas Ahlburg, ${ }^{[a]}$ Peter Fristrup, ${ }^{[a]}$ Per-Ola Norrby, ${ }^{[b, c]}$ and Robert Madsen ${ }^{*[a]}$
}

\begin{abstract}
The substrate scope and the mechanism have been investigated for the $\mathrm{MnCl}_{2}$-catalyzed cross coupling reaction between aryl halides and Grignard reagents. The transformation proceeds rapidly and in good yield when the aryl halide is a chloride containing a cyano or an ester group in the para position or a cyano group in the ortho position. A range of other substituents gave no conversion of the aryl halide or led to the formation of side products. A broader scope was observed for the Grignard reagents where a variety of alkyl- and arylmagnesium chlorides participated in the coupling. Two radical clock experiments were performed which in both cases succeeded in trapping an intermediate aryl radical. The cross coupling is therefore believed to proceed by a $S_{R N} 1$ mechanism, where a triorganomanganate complex serves as the most likely nucleophile and single electron donor. Other mechanistic scenarios were excluded based on the substrate scope of the aryl halide.
\end{abstract}

\section{Introduction}

The palladium-catalyzed cross coupling reaction has been one of the most important discoveries in organic chemistry over the past 50 years. ${ }^{[1]}$ The reaction has had a tremendous impact on the pharmaceutical industry where it accounts for about $10 \%$ of all reactions used in the synthesis of drug candidates. ${ }^{[2]}$ The reaction, however, suffers from one major drawback which is the use of the metal palladium. This metal does not occur naturally in the human body and all palladium compounds are considered toxic. ${ }^{[3]}$ Furthermore, palladium is a precious metal with a low annual production. This has prompted a thorough search for alternative catalysts where nickel complexes have been extensively investigated, ${ }^{[4]}$ but are more toxic than the palladium counterparts. ${ }^{[3]}$ Recently, copper ${ }^{[5]}$ iron $^{[6]}$ and cobalt ${ }^{[7]}$ complexes have gained much attention, but often high catalyst loadings are required. As a result, there is still a demand for effective, cheap and non-toxic catalysts for the cross coupling reaction.

[a] G. Antonacci, A. Ahlburg, Dr. P. Fristrup, Prof. Dr. R. Madsen Department of Chemistry

Technical University of Denmark

2800 Kgs. Lyngby (Denmark)

E-mail: rm@kemi.dtu.dk

[b] Prof. Dr. Per-Ola Norrby

Department of Chemistry and Molecular Biology

University of Gothenburg

Kemigården 4, 412 96, Göteborg (Sweden)

[c] Prof. Dr. Per-Ola Norrby

Pharmaceutical Sciences

AstraZeneca

Pepparedsleden 1, 43183 Mölndal (Sweden)

Supporting information for this article is given via a link at the end of the document.
This has inspired research into manganese catalysts since manganese is one of the cheapest metals and is also present in all living organisms. Although, the general application of manganese in homogeneous catalysis is rapidly increasing, ${ }^{[8]}$ the metal has still only found limited applications for the cross coupling reaction. To date, only four publications describe the manganese-catalyzed coupling between aryl/alkenyl halides and Grignard reagents where $\mathrm{MnCl}_{2}$ is used as the catalyst in all cases. ${ }^{[9-11]}$ This includes the coupling of activated aryl halides, ${ }^{[9]}$ reactive heterocyclic chlorides ${ }^{[10]}$ and alkenyl halides ${ }^{[11]}$ with both alkyl- and arylmagnesium halides. No information is provided about the mechanism of these manganese-catalyzed reactions.

We envisaged that the scope of the $\mathrm{MnCl}_{2}$-catalyzed coupling between aryl halides and Grignard reagents could be expanded, possibly by gaining an understanding of the reaction mechanism. Some of us have previously studied the reactivity of Grignard reagents ${ }^{[12]}$ and investigated the mechanism of the iron-catalyzed cross coupling ${ }^{[13]}$ and the Barbier allylation. ${ }^{[14]} \mathrm{We}$ decided to use the $\mathrm{MnCl}_{2}$-catalyzed cross coupling between activated aryl halides and aryl/alkyl Grignard reagents as a starting point for our investigation. ${ }^{[9]}$ In this transformation, ochlorobenzonitrile undergoes a successful reaction with the organomagnesium halides in THF solution with $10 \%$ of the catalyst. ${ }^{[9]}$ In addition, both $o$ - and $p$-chlorobenzaldehyde $N$ butylimine can be coupled with the Grignard reagents under the same conditions. ${ }^{[9]}$ However, this is a very narrow range of substrates and it would be interesting to exploit the transformation with a broader array of aryl halides. Herein, we describe the substrate scope and limitations for the manganesecatalyzed cross coupling of aryl halides with Grignard reagents and elucidate part of the reaction mechanism.

\section{Results and Discussion}

The studies began by investigating the reaction between cyclohexylmagnesium chloride and various para-substituted halobenzenes (Table 1). The coupling afforded a $94 \%$ yield with p-chlorobenzonitrile (entry 1) while methyl p-chlorobenzoate gave $65 \%$ yield (entry 2 ). The transformation was performed in THF since the coupling with $p$-chlorobenzonitrile gave a higher yield in this solvent than in diethyl ether, dioxane, DME or toluene. In addition, the best results with this substrate were obtained with $\mathrm{MnCl}_{2}$ as the catalyst while a lower yield was achieved with $\mathrm{MnBr}_{2}$ and no coupling occurred with $\mathrm{MnF}_{2}, \mathrm{Mnl}_{2}$ or in the absence of a manganese salt. The use of additives such as $\mathrm{LiCl}$ and $\mathrm{MgBr}_{2}$ also led to lower yields. $\mathrm{MnCl}_{2}$ is not soluble in THF, but dissolves upon addition of the Grignard reagents to afford a brown solution. Chloride appears to be the preferred leaving group since only a $43 \%$ yield was obtained 
with $p$-bromobenzonitrile (entry 3 ) while $p$-iodobenzonitrile underwent complete dehalogenation (entry 4).

Table 1. Coupling with cyclohexylmagnesium bromide.

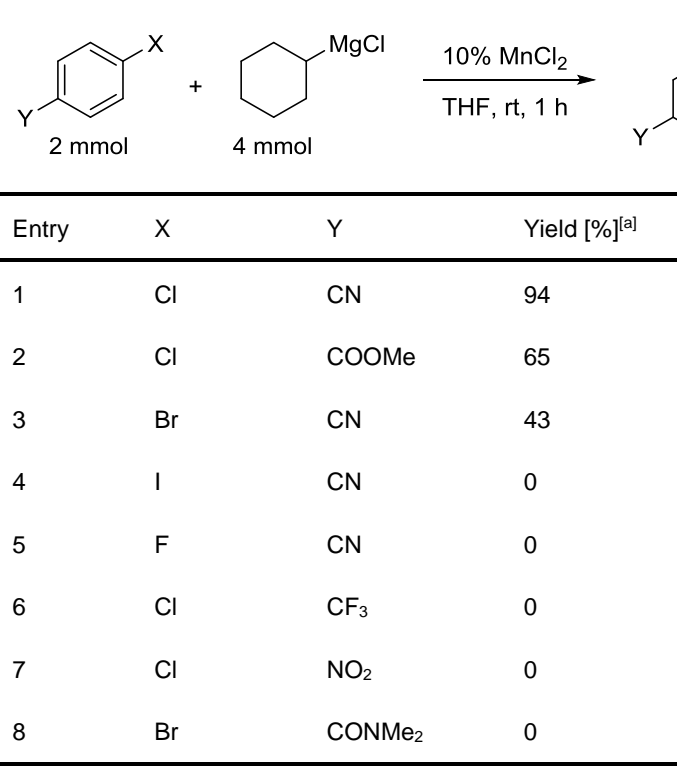

[a] Isolated yield.

Attempts to extend the coupling to a variety of other parasubstituted halobenzenes were not successful. No reaction was observed when $p$-fluorobenzonitrile and $p$-chlorobenzotrifluoride were mixed with the Grignard reagent under the optimized conditions (entries 5 and 6) which are important observations for understanding the mechanism of the coupling. The trifluoromethyl and the cyano group are both electronwithdrawing groups with Hammett constants around $0.6^{[15]}$ and the vast difference in reactivity between these groups indicates that an oxidative addition to the aryl chloride is not part of the reaction pathway. The fact that the chloro substrate reacts well with the Grignard reagent while the fluoro compound is unreactive shows that the transformation does not proceed by a $\mathrm{S}_{\mathrm{N}} \mathrm{Ar}$ mechanism through an intermediate Meisenheimer adduct with the addition as the rate-determining step.

A number of other para-substituted halobenzenes were also unreactive or led to side reactions. $p$-Chloronitrobenzene reacted with the Grignard reagent at the nitro group (entry 7) which is a known transformation for organomagnesium halides ${ }^{[16]}$ whereas no reaction was observed with $\mathrm{N}, \mathrm{N}$-dimethyl $p$-bromobenzamide (entry 8). p-Chlorobenzaldehyde and acetophenone underwent addition to the carbonyl group while chlorobenzenes with a methyl, phenyl, bromo, methoxy or methylthio substituent in the para position did not react with cyclohexylmagnesium chloride (results not shown). The metasubstituted substrate, $m$-chlorobenzonitrile, did not react either under the optimized conditions.

The coupling could be extended to other Grignard reagents as shown in the reaction with $p$-chlorobenzonitrile (Table 2, entries $1-7$ ). The transformation gave moderate to good yields with a variety of different aryl- and alkylmagnesium halides. The corresponding o-chlorobenzonitrile underwent a similar coupling with the Grignard reagents and the yields were close to the results obtained for the para substrate (Table 2, entries 8 -12). Both substrates were also reacted with allylmagnesium chloride, but the results were difficult to reproduce although the substitution product was obtained in moderate yields in some cases. In addition, the different Grignard reagents were reacted with $p$-chlorobenzotrifluoride, $p$-chloroanisole and $m$ chlorobenzonitrile, but no conversion of these chlorobenzenes was observed which is in line with the results in Table 1. The reaction between methyl $p$-chlorobenzoate and phenylmagnesium chloride gave substitution at the ester group and no reaction occurred with the halide. The same substitution to produce the ketone was observed when $p$ chlorophenylmagnesium bromide, $p$-methoxyphenylmagnesium bromide and allylmagnesium chloride were reacted with methyl p-chlorobenzoate.

Table 2. Coupling with $p$ - and o-chlorobenzonitrile.

\begin{tabular}{lllll} 
& & & \\
\hline
\end{tabular}

[a] Isolated yield. [b] Yield based on NMR since the isolated product could not be obtained completely pure.

The influence of the temperature and the reaction time was investigated with $p$-chlorobenzonitrile and phenylmagnesium chloride. No reaction occurred at $-12{ }^{\circ} \mathrm{C}$ while at $0{ }^{\circ} \mathrm{C}$ about $5 \%$ of the product was formed after 2 hours. At $6{ }^{\circ} \mathrm{C}$ almost $80 \%$ of the chloronitrile was consumed after only 1 minute followed by very little further consumption of the starting material over the next $30 \mathrm{~min}$. At room temperature the coupling essentially went 
to completion within 1 minute after which time the solvent was refluxing due to the exothermic nature of the reaction.

To further probe the influence of the Grignard reagent, a competition experiment was set up in which $p$-chlorobenzonitrile was allowed to react with a mixture of phenyl- and cyclohexylmagnesium chloride (i.e. a contest between the reactions in Table 1, entry 1 and Table 2, entry 1 ). This resulted in immediate formation of $p$-cyclohexylbenzonitrile and very little of $p$-phenylbenzonitrile which shows that the most nucleophilic Grignard reagent is also the most reactive. An additional competition experiment was set up in which cyclohexylmagnesium chloride was allowed to react with a mixture of $p$-chlorobenzonitrile and methyl $p$-chlorobenzoate (i.e. a contest between the reactions in entry 1 and 2 in Table 1). In this case, the two substitution products were formed in equal amounts and the $p$-cyano and the $p$-methyl ester substituents therefore display a similar influence on the reactivity of the aryl halide.<smiles>N#Cc1ccc(Cl)cc1C#N</smiles><smiles>N#Cc1ccc(C#N)c(Cl)c1</smiles><smiles>N#Cc1ccc(Cl)cc1Cl</smiles><smiles>N#Cc1c(Cl)cccc1Cl</smiles>

Scheme 1. Coupling of chloromethylbenzonitriles.

These results show that the substrate scope of the cross coupling is limited under the present conditions. However, the transformation is still very fast with a narrow range of ortho- and para-substituted aryl halides and the mechanism must therefore involve a pathway where these substituents are essential. As mentioned above, the reaction is not operating by a classical $\mathrm{S}_{\mathrm{N}} \mathrm{Ar}$ route or through an oxidative addition pathway as known for the corresponding palladium- and nickel-catalyzed reactions. This raises the question whether a radical pathway is involved, i.e. a $\mathrm{S}_{\mathrm{RN}} 1$ mechanism. ${ }^{[18]}$ Alkali metal enolates and a few other carbanions have previously been reacted with halobenzenes through a $\mathrm{S}_{\mathrm{RN}} 1$ pathway, ${ }^{[18]}$ but whether Grignard reagents are able to react with aryl radicals is still a matter of debate. ${ }^{[19]}$

Figure 1. Substrates investigated for the Hammett study.

A Hammett study was also considered because it may provide information about the nature of the intermediate species in the coupling. ${ }^{[17]}$ Since the reaction gives the best results with $o$ - and $p$-chlorobenzonitrile, differently substituted analogs of these were investigated as possible substrates for the kinetic study (Figure 1 and Scheme 1). Unfortunately, analogs $\mathbf{1 - 4}$ all led to mixtures of several products when reacted with cyclohexylmagnesium chloride. Only with methyl substituted analogs $\mathbf{5}-\mathbf{7}$ was it possible to obtain one coupling product $\mathbf{8}$ 10 upon reaction with the cyclohexyl Grignard reagent and $\mathrm{MnCl}_{2}$ (Scheme 1). The yields ranged from $88 \%$ and $81 \%$ with 5 and 7 to $62 \%$ with 6 . It is noteworthy that compound 6 can be coupled at all since the halide and the cyano group are positioned meta to each other.

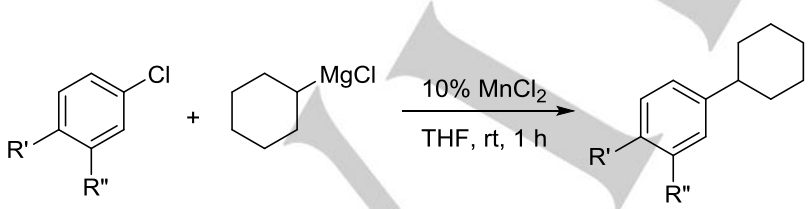

5: $\mathrm{R}^{\prime}=\mathrm{CN}, \mathrm{R}^{\prime \prime}=\mathrm{Me}$

8: $R^{\prime}=C N, R^{\prime \prime}=M e: 88 \%$

6: $\mathrm{R}^{\prime}=\mathrm{Me}, \mathrm{R}^{\prime \prime}=\mathrm{CN}$

9: $\mathrm{R}^{\prime}=\mathrm{Me}, \mathrm{R}^{\prime \prime}=\mathrm{CN}: 62 \%$

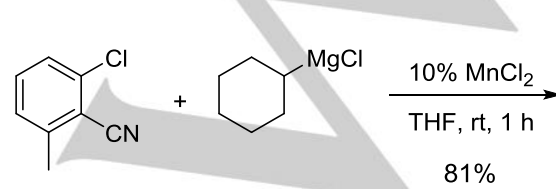

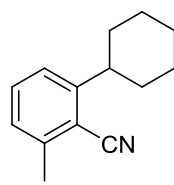

10
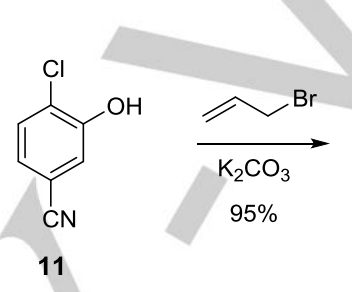<smiles>C=CCOc1cc(C#N)ccc1Cl</smiles>

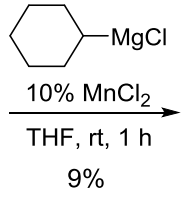<smiles>CC1COc2cc(C#N)ccc21</smiles>

13

15
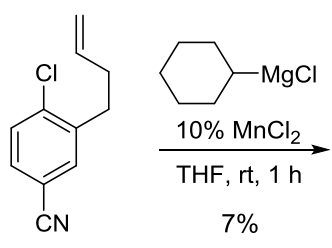<smiles>CC1CCc2cc(C#N)ccc21</smiles>

12

14

16

Several experiments were therefore conducted in order to trap an intermediate aryl radical. First, the reaction between $p$ chlorobenzonitrile and cyclohexylmagnesium chloride was repeated in the presence of cyclohexa-1,4-diene in an attempt to dehalogenate the aryl chloride. However, the coupling still proceeded smoothly under these conditions and gave $p$ cyclohexylbenzonitrile as the only product. Then, a radical clock experiment was designed in which allyl ether $\mathbf{1 3}$ and the corresponding but-3-enyl compound $\mathbf{1 4}$ were reacted with cyclohexyl Grignard and $\mathrm{MnCl}_{2}$ (Scheme 2). The two olefinic chlorobenzonitriles were prepared by allylation from the corresponding phenol 11 and benzyl bromide 12. Compound 14 could not be obtained completely pure, but contained about $30 \%$ of a byproduct where the olefin had migrated. The reaction with cyclohexylmagnesium chloride gave in both cases a mixture of several compounds, but the main products arose from cyclization with the olefin and addition to the nitrile. The cyclization products $\mathbf{1 5}$ and $\mathbf{1 6}$ were isolated in $9 \%$ and $7 \%$ yield, respectively. Only very small amounts $(1-2 \%)$ were observed by GCMS from the direct cross coupling between the aryl halide and the Grignard reagent, but the products could not be isolated or further quantified. 


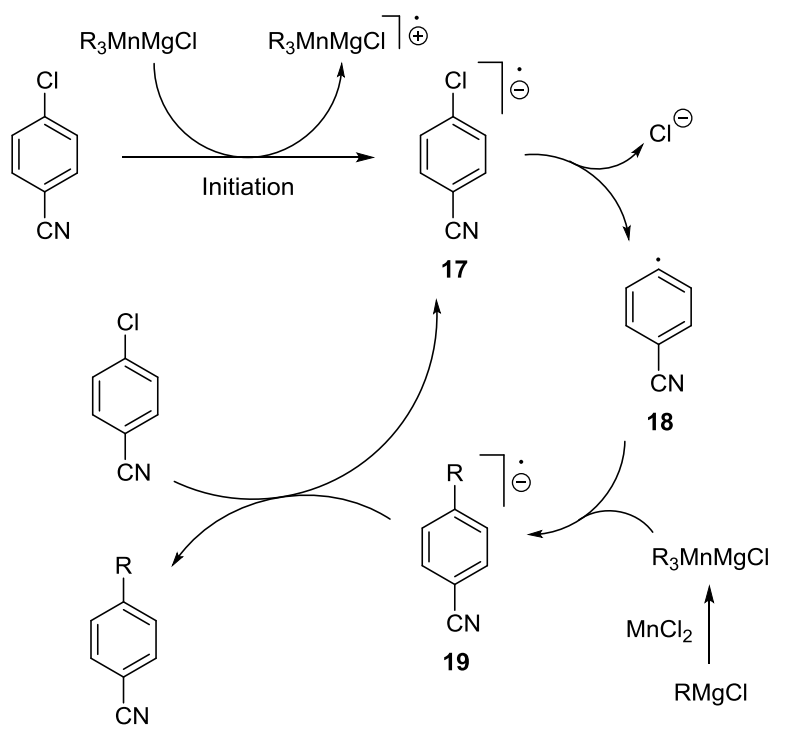

Scheme 3. Proposed mechanism for manganese-catalyzed cross coupling.

These results prompted us to propose the $\mathrm{S}_{\mathrm{RN}} 1$ mechanism in Scheme 3. The reduction of $p$-chlorobenzonitrile has been thoroughly studied since the resulting radical anion $\mathbf{1 7}$ is stabilized by the electron-withdrawing cyano group. ${ }^{[20]}$ It is unlikely that the Grignard reagent serves as the one-electron donor at $0{ }^{\circ} \mathrm{C}$. Since the transformation requires the presence of $\mathrm{MnCl}_{2}$, the initiator is probably the corresponding triorganomanganate complex which is known to mediate radical reactions ${ }^{[21]}$ and is easily formed from $\mathrm{MnCl}_{2}$ and an organomagnesium halide. ${ }^{[22]}$ The subsequent loss of chloride from the $p$-cyano radical anion is well-established and occurs with a three orders of magnitude higher rate than for the corresponding $m$-chlorobenzonitrile radical anion, ${ }^{[23]}$ which may explain the lack of reactivity of the meta substrate. The aryl radical $\mathbf{1 8}$ is electrophilic due to the cyano group and the ensuing nucleophilic attack can take place with either the triorganomanganate complex or with the Grignard reagent. Here, it should be noted that the transformation in Table 1, entry 1 also gives a fast reaction and a high yield with one equiv. of $\mathrm{MnCl}_{2}$ and under these conditions there is probably no free Grignard reagent present. Accordingly, the most likely nucleophile is the triorganomanganate complex which is known to be a softer nucleophile than a Grignard reagent. ${ }^{[22]}$ Rate constants for the reaction between aryl radicals and various nucleophiles have previously been determined and they are in most cases close to the diffusion limit. ${ }^{[24]}$ No homocoupling of the aryl halide was ever observed in any of the experiments which again points to a very rapid conversion of the intermediate aryl radical. Finally, the cycle is closed by SET from the radical ion 19 to the starting $p$-chlorobenzonitrile. The pathway may explain the limited substrate scope of the transformation since electron-withdrawing cyano/ester groups in the ortho or para positions are stabilizing radical anions 17 and 19 and at the same time facilitating the dechlorination to form the aryl radical.
The mechanistic proposal in Scheme 3 should be compared with the recently published cross coupling reaction between aryl iodides/bromides and aryl Grignard reagents in the absence of a catalyst. ${ }^{[25]}$ This reaction was performed in toluene at $110{ }^{\circ} \mathrm{C}$ for $24 \mathrm{~h}$ and allowed for coupling of ether and alkyl substituted aryl moieties. ${ }^{[25]}$ The mechanism was subsequently investigated and a radical clock experiment failed to produce the cyclization product from an aryl radical. ${ }^{[6]}$ DFT calculations suggested a pathway where the starting aryl halide $\mathrm{Ar}-\mathrm{X}$ is converted by SET into $[\mathrm{Ar}-\mathrm{X}]^{--}$which reacts with $\mathrm{Ar}-\mathrm{MgBr}$ to furnish a magnesium ion-radical cage $\left[\mathrm{Ar} \cdot{ }^{\cdot} \cdot \mathrm{Ar}^{\prime} \mathrm{MgBrX}\right]^{-} \cdot{ }^{[19]}$ The latter is transformed into a ArMgAr' radical anion from which $\left[\mathrm{Ar}-\mathrm{Ar}^{\prime}\right]^{--}$is formed followed by SET to $\mathrm{Ar}-\mathrm{X} .^{[19]}$

\section{Conclusions}

In summary, we have managed to exclude several commonly proposed catalytic cycles for the manganese-assisted coupling of Grignard reagents with aryl chlorides, and by inference, limited the mechanistic possibilities to one plausible reaction mechanism, $\mathrm{S}_{\mathrm{RN}} 1$. In line with this mechanism, a narrow aryl halide scope is observed, where only substituents allowing a single electron reduction followed by a facile halide dissociation give coupling. The proposed radical intermediate can be trapped by an internal radical clock substituent, but will prefer coupling with the Grignard reagent over base-stable intermolecular radical traps like cyclohexadiene. Substrates that will react directly with Grignard reagents, such as nitro-aromatics, ketones and aryl iodides, are not competent coupling partners. On the Grignard side, the scope is wider and allows for coupling of a variety of alkyl and arylmagnesium halides.

\section{Experimental Section}

General Information: All solvents were of HPLC grade and were not further purified. Gas chromatography was performed on a Shimadzu GCMS-QP2010S instrument fitted with an Equity $5,30 \mathrm{~m} \times 0.25 \mathrm{~mm} \times$ $0.25 \mu \mathrm{m}$ column. Flash column chromatography separations were performed on silica gel $60(40-63 \mu \mathrm{m})$. NMR spectra were recorded on a Bruker Ascend 400 spectrometer. Chemical shifts were measured relative to the signals of residual $\mathrm{CHCl}_{3}\left(\delta_{\mathrm{H}}=7.26 \mathrm{ppm}\right)$ and $\mathrm{CDCl}_{3}(\delta \mathrm{C}=$ $77.16 \mathrm{ppm}$ ). HRMS measurements were made using ESI with TOF detection. All Grignard reagents were obtained from commercial suppliers and titrated with a $0.06 \mathrm{M}$ solution of $\mathrm{I}_{2}$ in $\mathrm{Et}_{2} \mathrm{O}$ to determine the concentration: cyclohexylmagnesium chloride (1.6 $\mathrm{M}$ in $\left.\mathrm{Et}_{2} \mathrm{O}\right)$, phenylmagnesium bromide ( $0.9 \mathrm{M}$ in THF), p-methoxyphenylmagnesium bromide (0.3 $\mathrm{M}$ in THF), $p$-chlorophenylmagnesium bromide $(0.5 \mathrm{M}$ in $\left.\mathrm{Et}_{2} \mathrm{O}\right), p$-tolylmagnesium bromide (0.9 $\mathrm{M}$ in THF), $n$-butylmagnesium chloride (1.6 M in THF), isobutylmagnesium chloride (1.8 M in THF) and isopropylmagnesium bromide ( $0.8 \mathrm{M}$ in THF).

General Procedure for Cross Coupling: A dry three-neck Schlenk tube was equipped with a stir bar and a nitrogen inlet. The flask was flushed with nitrogen and charged with $\mathrm{MnCl}_{2}(25 \mathrm{mg}, 0.2 \mathrm{mmol})$ and dry THF (6 $\mathrm{mL}$ ). The mixture was stirred for about $10 \mathrm{~min}$ to completely dissolve $\mathrm{MnCl}_{2}$ followed by addition of the aryl halide $(2 \mathrm{mmol})$ and cooling to $0{ }^{\circ} \mathrm{C}$ in an ice bath. A solution of the Grignard reagent $(4 \mathrm{mmol})$ was added dropwise over $5 \mathrm{~min}$ and the ice bath was removed. The mixture was stirred for $1 \mathrm{~h}$ at ambient temperature. Decane $(0.4 \mathrm{~mL}, 2 \mathrm{mmol})$ was 
injected as an internal standard for determining the yield by GC and the reaction was quenched with saturated ammonium chloride solution (10 $\mathrm{mL})$. The mixture was extracted with EtOAc $(4 \times 10 \mathrm{~mL})$ and the combined organic layers were concentrated and the residue purified by flash column chromatography $\left(70 / 30\right.$ pentane $\left./ \mathrm{CH}_{2} \mathrm{Cl}_{2}\right)$.

4-Cyclohexylbenzonitrile: ${ }^{[27]}$ Table 1, Entry 1. Isolated as a colorless oil in $94 \%$ yield $(347 \mathrm{mg}) .{ }^{1} \mathrm{H} \mathrm{NMR}\left(400 \mathrm{MHz}, \mathrm{CDCl}_{3}\right): \delta=7.62-7.52(\mathrm{~m}, 2 \mathrm{H})$ 7.33-7.26 (m, 2H), 2.55 (tt, $J=9.1,2.6 \mathrm{~Hz}, 1 \mathrm{H}), 1.90-1.83(\mathrm{~m}, 4 \mathrm{H})$, $1.82-1.76(\mathrm{~m}, 1 \mathrm{H}), 1.44-1.36(\mathrm{~m}, 4 \mathrm{H}), 1.33-1.17(\mathrm{~m}, 1 \mathrm{H}) \mathrm{ppm} .{ }^{13} \mathrm{C} N M R$ $\left(100 \mathrm{MHz}, \mathrm{CDCl}_{3}\right): \delta=153.6,132.3,127.8,119.4,109.7,44.9,34.1,26.8$ $26.1 \mathrm{ppm}$. MS (EI): $\mathrm{m} / z=185[\mathrm{M}]^{+}$.

Methyl 4-cyclohexylbenzoate:[27] Table 1 , entry 2 . Isolated as a white solid $(430 \mathrm{mg}$ ) containing about $25 \%$ of cyclohexyl $p$-cyclohexylphenyl ketone which could not be separated. Yield $65 \%$. ${ }^{1} \mathrm{H}$ NMR $(400 \mathrm{MHz}$, $\left.\mathrm{CDCl}_{3}\right): \delta=7.98-7.90(\mathrm{~m}, 2 \mathrm{H}), 7.30-7.21(\mathrm{~m}, 2 \mathrm{H}), 3.87(\mathrm{~s}, 3 \mathrm{H}), 2.60$ $2.41(\mathrm{~m}, 1 \mathrm{H}), 2.01-1.61(\mathrm{~m}, 5 \mathrm{H}), 1.54-0.73(\mathrm{~m}, 5 \mathrm{H}) \mathrm{ppm} .{ }^{13} \mathrm{C}$ NMR $(100$ $\left.\mathrm{MHz}, \mathrm{CDCl}_{3}\right): \delta=167.3,153.6,129.8,127.8,127.0,52.0,44.8,34.6$, $27.1,26.4 \mathrm{ppm}$. MS (EI): $\mathrm{m} / \mathrm{z}=218[\mathrm{M}]^{+}$

[1,1'-Biphenyl]-4-carbonitrile:[28] Table 2, entry 1. Isolated as a yellowish solid in $93 \%$ yield $(334 \mathrm{mg}) .{ }^{1} \mathrm{H}$ NMR $\left(400 \mathrm{MHz}, \mathrm{CDCl}_{3}\right): \delta=$ 7.76-7.65 (m, 4H), 7.63-7.55 (m, 2H), 7.53-7.44 (m, 2H), 7.47-7.38 (m, 1H) ppm. ${ }^{13} \mathrm{C} \mathrm{NMR}\left(100 \mathrm{MHz}, \mathrm{CDCl}_{3}\right): \delta=145.8,139.3,132.7,129.2$, 128.8, 127.9, 127.4, 119.1, 111.1 ppm. MS (El): $\mathrm{m} / \mathrm{z}=179[\mathrm{M}]^{+}$

4'-Methoxy-[1,1'-biphenyl]-4-carbonitrile:[28] Table 2, entry 2. Prepared according to the general procedure where the Grignard reagent was added over $120 \mathrm{~min}$ at $0{ }^{\circ} \mathrm{C}$ to prevent a competing addition to the cyano group. Isolated as a white solid in $83 \%$ yield $(341 \mathrm{mg}) .{ }^{1} \mathrm{H}$ NMR (400 $\left.\mathrm{MHz}, \mathrm{CDCl}_{3}\right): \delta=7.71-7.67(\mathrm{~m}, 2 \mathrm{H}), 7.66-7.62(\mathrm{~m}, 2 \mathrm{H}), 7.57-7.50(\mathrm{~m}$, 2H), 7.04-6.97 (m, 2H), $3.87(\mathrm{~s}, 3 \mathrm{H}) \mathrm{ppm} .{ }^{13} \mathrm{C} \mathrm{NMR}\left(100 \mathrm{MHz}, \mathrm{CDCl}_{3}\right): \delta$ $=160.3,145.3,132.7,131.6,128.5,127.2,119.2,114.7,110.2,55.5$ ppm. MS (EI): $m / z=209[\mathrm{M}]^{+}$

4'-Chloro-[1,1'-biphenyl]-4-carbonitrile:[29] Table 2, entry 3. Prepared according to the general procedure where the reaction mixture was stirred for $2 \mathrm{~h}$ at $60{ }^{\circ} \mathrm{C}$ in an oil bath to ensure complete conversion of $p$ chlorobenzonitrile. Isolated as a white solid in $79 \%$ yield $(335 \mathrm{mg}) .{ }^{1} \mathrm{H}$ $\operatorname{NMR}\left(400 \mathrm{MHz}, \mathrm{CDCl}_{3}\right): \delta=7.73(\mathrm{~d}, J=8.0 \mathrm{~Hz}, 2 \mathrm{H}), 7.65(\mathrm{~d}, J=7.6 \mathrm{~Hz}$, 2H), $7.52(\mathrm{~d}, J=8.0 \mathrm{~Hz}, 2 \mathrm{H}), 7.45(\mathrm{~d}, J=7.6 \mathrm{~Hz}, 2 \mathrm{H}) \mathrm{ppm} .{ }^{13} \mathrm{C}$ NMR $\left(100 \mathrm{MHz}, \mathrm{CDCl}_{3}\right): \delta=144.5,137.7,135.1,132.9,129.5,128.6,127.7$, $118.9,111.4 \mathrm{ppm}$. MS (EI): $\mathrm{m} / z=213[\mathrm{M}]^{+}$.

4'-Methyl-[1,1'-biphenyl]-4-carbonitrile:[30] Table 2, entry 4. Prepared according to the general procedure where the Grignard reagent was added over $120 \mathrm{~min}$ at $0{ }^{\circ} \mathrm{C}$ to prevent a competing addition to the cyano group. Isolated as a white solid in $77 \%$ yield $(296 \mathrm{mg}) .{ }^{1} \mathrm{H}$ NMR $(400$ $\left.\mathrm{MHz}, \mathrm{CDCl}_{3}\right): \delta=7.63(\mathrm{~d}, J=8.5 \mathrm{~Hz}, 2 \mathrm{H}), 7.58(\mathrm{~d}, J=8.5 \mathrm{~Hz}, 2 \mathrm{H}), 7.43$ $7.39(\mathrm{~m}, 2 \mathrm{H}), 7.21(\mathrm{~d}, J=7.9 \mathrm{~Hz}, 2 \mathrm{H}), 2.34(\mathrm{~s}, 3 \mathrm{H}) \mathrm{ppm} .{ }^{13} \mathrm{C}$ NMR $(100$ $\left.\mathrm{MHz}, \mathrm{CDCl}_{3}\right): \delta=145.7,138.9,136.4,132.7,130.0,127.6,127.2,119.2$ $110.7,21.3 \mathrm{ppm}$. MS (El): $\mathrm{m} / z=193[\mathrm{M}]^{+}$.

4-Butylbenzonitrile: ${ }^{[31]}$ Table 2, entry 5 . Isolated as a colorless oil in $68 \%$ yield $(217 \mathrm{mg}) .{ }^{1} \mathrm{H} \mathrm{NMR}\left(400 \mathrm{MHz}, \mathrm{CDCl}_{3}\right): \delta=7.52(\mathrm{~d}, J=7.5 \mathrm{~Hz}$, $2 \mathrm{H}$ ), 7.25 (d, $J=7.2 \mathrm{~Hz}, 2 \mathrm{H}$ ), 2.64 (t, $J=7.8 \mathrm{~Hz}, 2 \mathrm{H}), 1.67-1.51$ (p, $J=$ $7.5 \mathrm{~Hz}, 2 \mathrm{H}), 1.33(\mathrm{q}, J=7.4 \mathrm{~Hz}, 2 \mathrm{H}), 0.91(\mathrm{t}, J=7.4 \mathrm{~Hz}, 3 \mathrm{H}) \mathrm{ppm} .{ }^{13} \mathrm{C}$ NMR $\left(100 \mathrm{MHz}, \mathrm{CDCl}_{3}\right): \delta=148.6,132.0,129.2,119.1,109.4,35.8$, $33.1,22.2,13.8 \mathrm{ppm}$. MS (El): $m / z=159[\mathrm{M}]^{+}$

4-Isobutylbenzonitrile:[32] Table 2, entry 6 . Isolated as a colorless oil $(290 \mathrm{mg}$ ) which could not be obtained completely pure. Yield $63 \%$ as estimated from the NMR spectrum. ${ }^{1} \mathrm{H}$ NMR $\left(400 \mathrm{MHz}, \mathrm{CDCl}_{3}\right): \delta=7.42$ $7.38(\mathrm{~m}, 2 \mathrm{H}), 7.12-7.08(\mathrm{~m}, 2 \mathrm{H}), 2.38(\mathrm{~d}, J=7.3 \mathrm{~Hz}, 2 \mathrm{H}), 1.74(\mathrm{dt}, J=$ 13.6, $6.8 \mathrm{~Hz}, 1 \mathrm{H}), 0.76(\mathrm{~d}, J=6.7 \mathrm{~Hz}, 6 \mathrm{H}) \mathrm{ppm} .{ }^{13} \mathrm{C}$ NMR $(100 \mathrm{MHz}$, $\left.\mathrm{CDCl}_{3}\right): \delta=147.3,131.9,129.8,129.7,119.1,109.5,45.4,30.0,22.2$ ppm. MS (EI): $m / z=159[\mathrm{M}]^{+}$

4-Isopropylbenzonitrile: ${ }^{[3]}$ Table 2, entry 7 . Isolated as a yellowish oil in $58 \%$ yield $(168 \mathrm{mg}) .{ }^{1} \mathrm{H}$ NMR $\left(400 \mathrm{MHz}, \mathrm{CDCl}_{3}\right): \delta=7.54-7.45(\mathrm{~m}$, $2 \mathrm{H}), 7.25(\mathrm{~d}, J=8.3 \mathrm{~Hz}, 2 \mathrm{H}), 2.88(\mathrm{~d}, J=6.9 \mathrm{~Hz}, 1 \mathrm{H}), 1.19(\mathrm{~d}, J=7.0 \mathrm{~Hz}$, 6H) ppm. ${ }^{13} \mathrm{C} \mathrm{NMR}\left(100 \mathrm{MHz}, \mathrm{CDCl}_{3}\right): \delta=154.4,132.2,127.3,119.2$ 109.6, 34.4, $23.5 \mathrm{ppm}$. MS (El): $\mathrm{m} / z=145[\mathrm{M}]^{+}$
2-Cyclohexylbenzonitrile: ${ }^{[34]}$ Table 2, entry 8 . Isolated as a colorless oil in $91 \%$ yield $(337 \mathrm{mg}) .{ }^{1} \mathrm{H}$ NMR $\left(400 \mathrm{MHz}, \mathrm{CDCl}_{3}\right): \delta=7.53-7.36(\mathrm{~m}$ $2 \mathrm{H}), 7.25(\mathrm{dd}, J=8.0,1.1 \mathrm{~Hz}, 1 \mathrm{H}), 7.14(\mathrm{td}, J=7.6,1.2 \mathrm{~Hz}, 1 \mathrm{H}), 2.93$ $2.77(\mathrm{~m}, 1 \mathrm{H}), 1.83-1.60(\mathrm{~m}, 5 \mathrm{H}), 1.42-1.25(\mathrm{~m}, 4 \mathrm{H}), 1.22-1.02(\mathrm{~m}, 1 \mathrm{H})$ ppm. ${ }^{13} \mathrm{C}$ NMR $\left(100 \mathrm{MHz}, \mathrm{CDCl}_{3}\right): \delta=151.3,132.8,132.7,126.4,126.2$ $118.1,111.7,42.7,33.5,26.5,25.8 \mathrm{ppm}$. MS (EI): $\mathrm{m} / \mathrm{z}=185[\mathrm{M}]^{+}$

[1,1'-Biphenyl]-2-carbonitrile: ${ }^{[35]}$ Table 2, entry 9. Isolated a as white solid in $90 \%$ yield $(321 \mathrm{mg}) .{ }^{1} \mathrm{H}$ NMR $\left(400 \mathrm{MHz}, \mathrm{CDCl}_{3}\right): \delta=7.75$ (td, $J=$ $6.3,1.5 \mathrm{~Hz}, 1 \mathrm{H}), 7.63(\mathrm{td}, J=7.8,1.5 \mathrm{~Hz}, 1 \mathrm{H}), 7.57-7.40(\mathrm{~m}, 7 \mathrm{H}) \mathrm{ppm}$. ${ }^{13} \mathrm{C}$ NMR $\left(100 \mathrm{MHz}, \mathrm{CDCl}_{3}\right): \delta=145.7,138.3,133.9,132.9,130.2,127.7$, $118.9,111.4 \mathrm{ppm}$. MS (El): $\mathrm{m} / z=179\left[\mathrm{M}^{+}\right.$.

4'-Methoxy-[1,1'-biphenyl]-2-carbonitrile::[35] Table 2, entry 10. Prepared according to the general procedure where the Grignard reagent was added over $120 \mathrm{~min}$ at $0{ }^{\circ} \mathrm{C}$ to prevent a competing addition to the cyano group. Isolated as a white solid in $80 \%$ yield $(336 \mathrm{mg}) .{ }^{1} \mathrm{H}$ NMR $\left(400 \mathrm{MHz}, \mathrm{CDCl}_{3}\right): \delta=7.74(\mathrm{dd}, J=7.8,1.3 \mathrm{~Hz}, 1 \mathrm{H}), 7.61$ (td, $J=7.7$, $1.4 \mathrm{~Hz}, 1 \mathrm{H}), 7.54-7.47(\mathrm{~m}, 3 \mathrm{H}), 7.39(\mathrm{td}, J=7.6,1.2 \mathrm{~Hz}, 1 \mathrm{H}), 7.05-6.99$ $(\mathrm{m}, 2 \mathrm{H}), 3.86(\mathrm{~s}, 3 \mathrm{H}) \mathrm{ppm} .{ }^{13} \mathrm{C} \mathrm{NMR}\left(100 \mathrm{MHz}, \mathrm{CDCl}_{3}\right): \delta=160.2,145.3$, 133.8, 132.9, 130.0, 127.1, 119.1, 114.3, 111.1, 55.5 ppm. MS (El): $\mathrm{m} / z$ $=209[\mathrm{M}]^{+}$

4'-Chloro-[1,1'-biphenyl]-2-carbonitrile:[35] Table 2, entry 11. Prepared according to the general procedure where the reaction mixture was stirred for $2 \mathrm{~h}$ at $60^{\circ} \mathrm{C}$ in an oil bath to ensure complete conversion of $p$ chlorobenzonitrile. Isolated as a white solid in $79 \%$ yield $(335 \mathrm{mg}) .{ }^{1} \mathrm{H}$ $\operatorname{NMR}\left(400 \mathrm{MHz}, \mathrm{CDCl}_{3}\right): \delta=7.77(\mathrm{dd}, J=7.7,1.3 \mathrm{~Hz}, 1 \mathrm{H}), 7.65$ (td, $J=$ 7.5, $1.3 \mathrm{~Hz}, 2 \mathrm{H}), 7.52-7.44(\mathrm{~m}, 7 \mathrm{H}) \mathrm{ppm} .{ }^{13} \mathrm{C}$ NMR $\left(100 \mathrm{MHz}, \mathrm{CDCl}_{3}\right)$ : $\delta=144.3,136.7,135.2,133.9,133.1,130.2,128.0,118.6,111.4 \mathrm{ppm}$ MS (EI): $m / z=213[\mathrm{M}]^{+}$

4'-Methyl-[1,1'-biphenyl]-2-carbonitrile:[36] Table 2, entry 12. Prepared according to the general procedure where the Grignard reagent was added over $120 \mathrm{~min}$ at $0{ }^{\circ} \mathrm{C}$ to prevent a competing addition to the cyano group. Isolated as a white solid in $78 \%$ yield $(302 \mathrm{mg}) .{ }^{1} \mathrm{H} \mathrm{NMR}(400 \mathrm{MHz}$, $\left.\mathrm{CDCl}_{3}\right): \delta=7.70(\mathrm{dd}, J=7.8,1.3 \mathrm{~Hz}, 1 \mathrm{H}), 7.57(\mathrm{td}, J=7.7,1.4 \mathrm{~Hz}, 1 \mathrm{H})$ $7.47-7.39(\mathrm{~m}, 3 \mathrm{H}), 7.36(\mathrm{td}, J=7.6,1.3 \mathrm{~Hz}, 1 \mathrm{H}), 7.25(\mathrm{~d}, J=7.8 \mathrm{~Hz}, 2 \mathrm{H})$, 2.37 (s, 3H) ppm. ${ }^{13} \mathrm{C}$ NMR $\left(100 \mathrm{MHz}, \mathrm{CDCl}_{3}\right): \delta=145.6,138.7,135.3$ 133.7, 132.8, 130.0, 129.5, 128.6, 127.3, 111.2, $21.4 \mathrm{ppm}$. MS (EI): $\mathrm{m} / \mathrm{z}$ $=193[\mathrm{M}]^{+}$.

4-Cyclohexyl-2-methylbenzonitrile (8): ${ }^{[34]}$ Isolated as a colorless oil $(384 \mathrm{mg}$ ) which could not be obtained completely pure. Yield $88 \%$ as estimated from the NMR spectrum. ${ }^{1} \mathrm{H}$ NMR $\left(400 \mathrm{MHz}, \mathrm{CDCl}_{3}\right): \delta=7.66-$ $7.54(\mathrm{~m}, 1 \mathrm{H}), 7.46-7.31(\mathrm{~m}, 1 \mathrm{H}), 7.20(\mathrm{~d}, J=8.0 \mathrm{~Hz}, 1 \mathrm{H}), 2.80-2.35(\mathrm{~m}$ $4 \mathrm{H}), 2.02-1.75(\mathrm{~m}, 5 \mathrm{H}), 1.71-1.15(\mathrm{~m}, 5 \mathrm{H}) \mathrm{ppm} .{ }^{13} \mathrm{C}$ NMR $(100 \mathrm{MHz}$, $\left.\mathrm{CDCl}_{3}\right): \delta=153.5,141.9,133.7,132.6,130.6,129.0,126.9,125.0,110.1$, 44.8, 34.1, 26.8, 26.1, 20.6 ppm. MS (El): $\mathrm{m} / z=199[\mathrm{M}]^{+}$.

5-Cyclohexyl-2-methylbenzonitrile (9): Isolated as a colorless oil in $62 \%$ yield $(246 \mathrm{mg}) .{ }^{1} \mathrm{H}$ NMR $\left(400 \mathrm{MHz}, \mathrm{CDCl}_{3}\right): \delta=7.61(\mathrm{~d}, J=8.0 \mathrm{~Hz}$, $1 \mathrm{H}), 7.29-7.15(\mathrm{~m}, 2 \mathrm{H}), 2.66-2.60(\mathrm{~m}, 4 \mathrm{H}), 2.10-1.75(\mathrm{~m}, 5 \mathrm{H}), 1.63-1.26$ $(\mathrm{m}, 5 \mathrm{H}) \mathrm{ppm} .{ }^{13} \mathrm{C}$ NMR $\left(100 \mathrm{MHz}, \mathrm{CDCl}_{3}\right): \delta=153.4,132.5,128.9$, 124.9, 118.6, 110.0, 44.8, 34.0, 26.7, 26.0, 20.6 ppm. HRMS: calcd for $\mathrm{C}_{14} \mathrm{H}_{18} \mathrm{~N} 200.1434[\mathrm{M}+\mathrm{H}]^{+}$, found: 200.1436

2-Cyclohexyl-6-methylbenzonitrile (10): ${ }^{[34]}$ Isolated as a white solid in $81 \%$ yield $(322 \mathrm{mg}) .{ }^{1} \mathrm{H}$ NMR $\left(400 \mathrm{MHz}, \mathrm{CDCl}_{3}\right): \delta=7.40(\mathrm{t}, J=7.8 \mathrm{~Hz}$ $1 \mathrm{H}), 7.17(\mathrm{~d}, J=7.9 \mathrm{~Hz}, 1 \mathrm{H}), 7.12(\mathrm{~d}, J=7.6 \mathrm{~Hz}, 1 \mathrm{H}), 2.98(\mathrm{tt}, J=11.3$ $3.1 \mathrm{~Hz}, 1 \mathrm{H}), 2.53(\mathrm{~s}, 3 \mathrm{H}), 1.95-1.72(\mathrm{~m}, 5 \mathrm{H}), 1.57-1.35(\mathrm{~m}, 4 \mathrm{H}), 1.34$ $1.17(\mathrm{~m}, 1 \mathrm{H}) \mathrm{ppm} .{ }^{13} \mathrm{C} \mathrm{NMR}\left(100 \mathrm{MHz}, \mathrm{CDCl}_{3}\right): \delta=151.9,142.3,132.4$ $127.5,123.7,117.3,112.5,43.1,33.9,26.8,26.1,21.1$ ppm. MS (EI) $\mathrm{m} / \mathrm{z}=199[\mathrm{M}]^{+}$

3-(Allyloxy)-4-chlorobenzonitrile (13): A mixture of 4-chloro-3hydroxybenzonitrile $(1 \mathrm{~g}, 6.5 \mathrm{mmol})$, allyl bromide $(0.6 \mathrm{~mL}, 7.1 \mathrm{mmol})$ and $\mathrm{K}_{2} \mathrm{CO}_{3}(1 \mathrm{~g}, 7.2 \mathrm{mmol})$ in acetone $(50 \mathrm{~mL})$ was stirred under reflux. The reaction was monitored by TLC and additional allyl bromide $(0.6 \mathrm{~mL}, 7.1$ $\mathrm{mmol}$ ) and $\mathrm{K}_{2} \mathrm{CO}_{3}(1 \mathrm{~g}, 7.2 \mathrm{mmol})$ were added after $20 \mathrm{~min}$. After two hours, the reaction was diluted with water and extracted with diethyl ether. The organic layers were concentrated to give $1.2 \mathrm{~g}(95 \%)$ of a brown solid. ${ }^{1} \mathrm{H}$ NMR (400 MHz, $\left.\mathrm{CDCl}_{3}\right): \delta=7.47(\mathrm{~d}, J=8.1 \mathrm{~Hz}, 1 \mathrm{H}), 7.20(\mathrm{~d}, J$ 
$=8.1 \mathrm{~Hz}, 1 \mathrm{H}), 7.14(\mathrm{~s}, 1 \mathrm{H}), 6.04(\mathrm{ddd}, J=15.8,10.5,5.2 \mathrm{~Hz}, 1 \mathrm{H}), 5.48(\mathrm{~d}$, $J=15.8 \mathrm{~Hz}, 1 \mathrm{H}$ ), $5.37(\mathrm{~d}, J=10.5 \mathrm{~Hz}, 1 \mathrm{H}), 4.64(\mathrm{~d}, J=5.0 \mathrm{~Hz}, 2 \mathrm{H}) \mathrm{ppm}$. ${ }^{13} \mathrm{C} \mathrm{NMR}\left(100 \mathrm{MHz}, \mathrm{CDCl}_{3}\right): \delta=154.6,131.6,131.3,129.0,125.3,118.9$ 118.2, 116.4, 111.5, 70.1 ppm. HRMS: calcd for $\mathrm{C}_{10} \mathrm{H}_{8} \mathrm{CINNaO} 216.0186$ $[\mathrm{M}+\mathrm{Na}]^{+}$, found: 216.0188 .

3-(But-3-en-1-yl)-4-chlorobenzonitrile (14): The procedure is inspired by a literature protocol for Suzuki couplings with benzyl bromides. ${ }^{37} \mathrm{~A}$ mixture of 3-(bromomethyl)-4-chlorobenzonitrile ${ }^{38}(2.4 \mathrm{~g}, 10 \mathrm{mmol})$, bis(triphenylphosphine)palladium(II) dichloride $(0.75 \mathrm{~g}, 1 \mathrm{mmol})$, tri $(o-$ tolyl)phosphine (325 mg, $10 \mathrm{mmol})$, allylboronic acid pinacol ester $(1.97 \mathrm{~g}$ $12 \mathrm{mmol})$ and $\mathrm{Na}_{2} \mathrm{CO}_{3}(2.15 \mathrm{~g}, 20 \mathrm{mmol})$ in aqueous acetonitrile $(1 / 10$ $\mathrm{H}_{2} \mathrm{O} / \mathrm{MeCN}, 100 \mathrm{~mL}$ ) was stirred at reflux for $2 \mathrm{~h}$. Water was added and the mixture was extracted with $\mathrm{Et}_{2} \mathrm{O}$. The organic layers were concentrated and the residue purified by column chromatography $(4 / 1$ pentate $/ \mathrm{CH}_{2} \mathrm{Cl}_{2}$ ) to give $439.5 \mathrm{mg}(22 \%)$ of the product as a brown oil, which contained about $30 \%$ of a byproduct where the olefin had migrated. ${ }^{1} \mathrm{H}$ NMR $\left(400 \mathrm{MHz}, \mathrm{CDCl}_{3}\right): \delta=7.45(\mathrm{~d}, J=1.7 \mathrm{~Hz}, 1 \mathrm{H}), 7.40-7.38(\mathrm{~m}$, $2 \mathrm{H}$ ), 5.78 (ddt, $J=16.9,10.3,6.5 \mathrm{~Hz}, 1 \mathrm{H}$ ), 5.02-4.98 (m, 1H), 4.98-4.95 $(\mathrm{m}, 1 \mathrm{H}), 2.80(\mathrm{dd}, J=8.7,6.7 \mathrm{~Hz}, 2 \mathrm{H}), 2.37-2.29(\mathrm{~m}, 2 \mathrm{H}) \mathrm{ppm} .{ }^{13} \mathrm{C}$ NMR $\left(100 \mathrm{MHz}, \mathrm{CDCl}_{3}\right): \delta=141.1,139.3,136.7,133.9,130.8,130.5,118.2$, 116.1, 110.8, 33.1, $32.8 \mathrm{ppm}$. HRMS: calcd for $\mathrm{C}_{11} \mathrm{H}_{11} \mathrm{CINNa} 214.0394$ $[\mathrm{M}+\mathrm{Na}]^{+}$, found: 214.0401 .

3-Methyl-2,3-dihydrobenzofuran-6-carbonitrile (15): Allyl ether 13 (386 mg, $2 \mathrm{mmol}$ ) was reacted with cyclohexylmagnesium chloride and $\mathrm{MnCl}_{2}$ as described above in the general procedure to give $30.1 \mathrm{mg}(9 \%)$ of the product as a brown oily solid. ${ }^{1} \mathrm{H} \mathrm{NMR}\left(400 \mathrm{MHz}, \mathrm{CDCl}_{3}\right): \delta=7.21$ $(\mathrm{d}, J=7.7 \mathrm{~Hz}, 1 \mathrm{H}), 7.17$ (dd, $J=7.7,1.3 \mathrm{~Hz}, 1 \mathrm{H}), 6.99(\mathrm{~d}, J=1.2 \mathrm{~Hz}, 1 \mathrm{H})$ $4.74(\mathrm{t}, J=9.0 \mathrm{~Hz}, 1 \mathrm{H}), 4.14(\mathrm{dd}, J=8.8,7.4 \mathrm{~Hz}, 1 \mathrm{H}), 3.65-3.50(\mathrm{~m}, 1 \mathrm{H})$, $1.34(\mathrm{~d}, J=6.9 \mathrm{~Hz}, 3 \mathrm{H}) \mathrm{ppm} .{ }^{13} \mathrm{C} \mathrm{NMR}\left(100 \mathrm{MHz}, \mathrm{CDCl}_{3}\right): \delta=160.0$, $138.5,125.3,124.7,119.2,112.7,111.6,79.1,36.6,19.1$ ppm. HRMS: calcd for $\mathrm{C}_{10} \mathrm{H}_{9} \mathrm{NNaO} 182.0576[\mathrm{M}+\mathrm{Na}]^{+}$, found: 182.0577 .

1-Methyl-2,3-dihydro-1H-indene-5-carbonitrile (16): Butenyl compound 14 (382 mg, $2 \mathrm{mmol}$, including $30 \%$ of the olefin isomer) was reacted with cyclohexylmagnesium chloride and $\mathrm{MnCl}_{2}$ as described above in the general procedure to give $21.7 \mathrm{mg}(7 \%)$ of the product as a colorless solid. ${ }^{1} \mathrm{H}$ NMR $\left(400 \mathrm{MHz}, \mathrm{CDCl}_{3}\right): \delta=7.47(\mathrm{~s}, 1 \mathrm{H}), 7.46(\mathrm{~d}, \mathrm{~J}=$ $7.5 \mathrm{~Hz}, 1 \mathrm{H}$ ), $7.25(\mathrm{~d}, J=7.1 \mathrm{~Hz}, 1 \mathrm{H}), 3.27-3.17(\mathrm{~m}, 1 \mathrm{H}), 2.94$ (ddd, $J=$ 16.2, 8.7, $4.0 \mathrm{~Hz}, 1 \mathrm{H}$ ), 2.86 (dt, $J=16.4,8.5 \mathrm{~Hz}, 1 \mathrm{H}$ ), 2.35 (dtt, $J=11.4$, 7.4, 3.7 Hz, $1 \mathrm{H}), 1.65(\mathrm{dq}, J=12.6,8.7 \mathrm{~Hz}, 1 \mathrm{H}), 1.30(\mathrm{~d}, J=6.9 \mathrm{~Hz}, 3 \mathrm{H})$ ppm. ${ }^{13} \mathrm{C}$ NMR $\left(100 \mathrm{MHz}, \mathrm{CDCl}_{3}\right): \delta=154.6,145.2,130.7,128.1,124.1$, 119.8, 109.9, 39.9, 34.5, 31.3, 19.5 ppm. HRMS: calcd for $\mathrm{C}_{11} \mathrm{H}_{12} \mathrm{~N}$ $158.0964[\mathrm{M}+\mathrm{H}]^{+}$, found: 158.0964 .

\section{Acknowledgements}

We thank the Danish Council for Independent Research Technology and Production Sciences for financial support (grant 1335-00153).

Keywords: cross-coupling $•$ Grignard reagent $•$ manganese $•$ radical reactions $\cdot$ reaction mechanisms

[1] C. C. C. J. Seechurn, M. O. Kitching, T. J. Colacot, V. Snieckus, Angew. Chem. Int. Ed. 2012, 51, 5062-5085; Angew. Chem. 2012, 124, 5150-5174.

[2] S. D. Roughley, A. M. Jordan, J. Med. Chem. 2011, 54, 3451-3479.

[3] K. S. Egorova, V. P. Ananikov, Angew. Chem. Int. Ed. 2016, 55, 12150-12162; Angew. Chem. 2016, 128, 12334-12347.

[4] S. Z. Tasker, E. A. Standley, T. F. Jamison, Nature 2014, 509, 299-309.

[5] S. Thapa, B. Shrestha, S. K. Gurung, R. Giri, Org. Biomol. Chem. 2015, $13,4816-4827$.
[6] T. J. Mako, J. A. Byers, Inorg. Chem. Front. 2016, 3, 766-790.

[7] G. Cahiez, A. Moyeux, Chem. Rev. 2010, 110, 1435-1462.

[8] (a) J. R. Carney, B. R. Dillon, S. P. Thomas, Eur. J. Org. Chem. 2016 3912-3929. (b) W. Liu, L. Ackermann, ACS Catal. 2016, 6, 3743-3752. (c) D. A. Valyaev, G. Lavigne, N. Lugan, Coord. Chem. Rev. 2016, 308, 191-235.

[9] G. Cahiez, F. Lepifre, P. Ramiandrasoa, Synthesis 1999, 2138-2144.

[10] M. Rueping, W. leawsuwan, Synlett 2007, 247-250.

[11] (a) G. Cahiez, O. Gager, F. Lecomte, Org. Lett. 2008, 10, 5255-5256. (b) M. Alami, P. Ramiandrasoa, G. Cahiez, Synlett 1998, 325-327.

[12] (a) S. H. Christensen, T. Holm, R. Madsen, Tetrahedron 2014, 70, 4942-4946. (b) S. H. Christensen, T. Holm, R. Madsen, Tetrahedron 2014, 70, 1478-1483. (c) G. Osztrovszky, T. Holm, R. Madsen, Org. Biomol. Chem. 2010, 8, 3402-3404.

[13] (a) A. Hedström, Z. Izakian, I. Vreto, C.-J. Wallentin, P.-O. Norrby, Chem. Eur. J. 2015, 21, 5946-5953. (b) A. Hedström, E. Lindstedt, P.O. Norrby, J. Organomet. Chem. 2013, 748, 51-55. (c) J. Kleimark, P.F. Larsson, P. Emamy, A. Hedström, P.-O. Norrby, Adv. Synth. Catal. 2012, 354, 448-456.

[14] (a) J. H. Dam, P. Fristrup, R. Madsen, J. Org. Chem. 2008, 73 , 3228-3235. (b) L. Keinicke, P. Fristrup, P.-O. Norrby, R. Madsen, J. Am. Chem. Soc. 2005, 127, 15756-15781.

[15] C. Hansch, A. Leo, R. W. Taft, Chem. Rev. 1991, 91, 165-195.

[16] A. Ricci, M. Fochi, Angew. Chem. Int. Ed. 2003, 42, 1444-1446.

[17] For our previous studies of organometallic reagents by Hammett studies, see reference 14

[18] (a) R. A. Rossi, A. B. Pierini, A. B. Penenory, Chem. Rev. 2003, 103 71-167. (b) J. F. Bunnett, Acc. Chem. Res. 1978, 11, 413-420.

[19] B. E. Haines, O. Wiest, J. Org. Chem. 2014, 79, 2771-2774.

[20] (a) I. V. Beregovaya, V. P. Vysotskii, L. N. Shegoleva, J. Struct. Chem. 2006, 47, 211-219. (b) D. Laage, I. Burghardt, T. Sommerfeld, J. T. Hynes, J. Phys. Chem. A 2003, 107, 11271-11291. (c) A. B. J. Parusel, R. Schamschule, G. Köhler, Croat. Chim. Acta 2000, 73, 359-366. (d) P. Neta, D. Behar, J. Am. Chem. Soc. 1981, 103, 103-106.

[21] J. Nakao, R. Inoue, H. Shinokubo, K. Oshima, J. Org. Chem. 1997, 62, 1910-1911.

[22] G. Cahiez, C. Duplais, J. Buendia, Chem. Rev. 2009, 109, 1434-1476.

[23] W. D. Geppert, N. Getoff, K. Sehested, J. Holcman, Radiat. Phys. Chem. 2000, 59, 39-47.

[24] C. Amatore, M. A. Oturan, J. Pinson, J.-M. Savéant, A. Thiébault, J. Am Chem. Soc. 1985, 107, 3451-3459.

[25] E. Shirakawa, Y. Hayashi, K. Itoh, R. Watabe, N. Uchiyama, W. Konagaya, S. Masui, T. Hayashi, Angew. Chem. Int. Ed. 2012, 51, 218-221; Angew. Chem. 2012, 124, 222-225.

[26] N. Uchiyama, E. Shirakawa, T. Hayashi, Chem. Commun. 2013, 49, 364-366.

[27] D. Liu, Y. Li, X. Qi, C. Liu, Y. Lan, A. Lei, Org. Lett. 2015, 17, 998-1001.

[28] B. Inés, R. SanMartin, M. J. Moure, E. Domínguez, Adv. Synth. Catal. 2009, 351, 2124-2132.

[29] C. Xu, L. Yin, B. Huang, H. Liu, M. Cai, Tetrahedron 2016, 72, 2065-2071.

[30] C. Liu, X. Rao, Y. Zhang, X. Li, J. Qiu, Z. Jin, Eur. J. Org. Chem. 2013, 4345-4350.

[31] W.-J. Guo, Z.-X. Wang, Tetrahedron 2013, 69, 9580-9585

[32] M. Härter, H. Beck, P. Ellinghaus, K. Berhörster, S. Greschat, K.-H. Thierauch, F. Süssmeier, U.S. Patent 20110301122A1, 2011.

[33] C. Qi, X. Hu, H. He, Synlett 2016, 27, 1979-1982.

[34] C.-Q. Tan, X. Zheng, Z. Ma, Y. Gu, Synth. Commun. 1999, 29, 123-127.

[35] L. Zhang, G. Y. Ang, S. Chiba, Org. Lett. 2010, 12, 3682-3685.

[36] C. Zhou, Q. Liu, Y. Li, R. Zhang, X. Fu, C. Duan, J. Org. Chem. 2012 77, 10468-10472.

[37] S. H. Shaber, M. C. H. Yap, K. G. Meyer, N. M. Niyaz, B. J. Rieder, M T. Sullenberger, W. R. Erickson, F. D. Smith, U.S. Patent 2006252755A1, 2006 
[38] M. Yoshida, T. Suzaki, Y. Kohara, H. Kuno, H. Nagabukuro, R. 
Entry for the Table of Contents (Please choose one layout)

Layout 1:

\section{FULL PAPER}

Text for Table of Contents

Layout 2:

\section{FULL PAPER}

$$
+\mathrm{R}^{\prime} \mathrm{MgCl} \underset{\text { THF }}{\stackrel{\mathrm{MnCl}_{2}}{\longrightarrow}}
$$

$\mathrm{R}$<smiles></smiles>

via<smiles>[R]c1ccccc1</smiles>

Formed by radicals: Aryl halides and Grignard reagents are coupled with $\mathrm{MnCl}_{2}$ as catalyst. The substrate scope and the mechanism are investigated, and an aryl radical is identified as an intermediate. As a result, the cross coupling is believed to proceed through a $\mathrm{S}_{\mathrm{RN}} 1$ mechanism.

Author(s), Corresponding Author(s)*

Page No. - Page No.

Title

((Insert TOC Graphic here: max. width: $5.5 \mathrm{~cm}$; max. height: $5.0 \mathrm{~cm}))$
Giuseppe Antonacci, Andreas Ahlburg, Peter Fristrup, Per-Ola Norrby, Robert Madsen*

Page No. - Page No.

Manganese-Catalyzed Cross Coupling of Aryl Halides and Grignard Reagents by a Radical Mechanism 